\section{Fatal pulmonary embolism following ankle fracture in a 23-year-old man}

\author{
Stella Charitidou, ${ }^{1}$ Theodoros Aslanidis, ${ }^{2}$ \\ Stellios Papalexandris ${ }^{3}$ \\ 'Emergency Department, General \\ Hospital of Ptolemaida; ${ }^{2}$ Mobile Intensive \\ Care Units, National Center of Emergency \\ Care, Thessaloniki Department, Greece; \\ ${ }^{3}$ Private Orthopedic Surgeon, \\ Manchester, UK
}

\section{Abstract}

Patients with lower extremity injuries are at increased risk of venous thromboembolism. We report a case of fatal pulmonary embolism following a simple ankle fracture in a 23 -yearold man. The diagnosis was confirmed postmortem. The incidence of such complications and the importance of deep venous prophylaxis in such cases are discussed.

\section{Introduction}

In many countries, most stable ankle fractures are treated conservatively in a belowknee plaster cast. It has been suggested that this method of immobilization may increase the risk of deep-vein thrombosis (DVT) because of inactivation of the ankle pump. ${ }^{1}$ However, the real incidence of venous thormboembolism (VTE) and pulmonary embolism (PE) in patients with ankle fracture is still unknown, as the diagnosis includes various types of anatomic injuries, thus the literature reports a wide range of incidence for both VTE and PE. Fatal PE after simple fracture is considered as rare. We report a case of a 23 -yearold man, with an ankle fracture who suffered a massive PE which was confirmed post-mortem and carry out a mini literature review upon the subject.

\section{Case Report}

A 23-year-old man (height $=179 \mathrm{~cm}$, weight $=83 \mathrm{~kg}$, body mass index=25) was transported to Emergency Department (ED) within half hour after the onset of severe shortness of breath chest pain, discomfort and agitation. Past medical history included a conservative treatment for minimal displaced left lateral malleolus fracture (Weber type B) 20 days before, which had been stabilized by a below-knee plaster of Paris caster. Medical regiment included only oral analgesics. Surgical and family history was non-contributory. He had no known drug allergies, no history of smoking, drug or alcohol abuse and no medical co-morbidities. On arrival, his Glasgow Coma Scale was E4/V5/M6, but 5 min later he collapsed in the ED. Immediate ventilation with $100 \% 0_{2}$ was initiated, intubation was carried out and resuscitation according to Advance Life Support guidelines initiated. First recorder electrocardiography was asystoly and arterial blood gases revealed severe metabolic and respiratory acidosis $\left(\mathrm{pH} 6.57 ; \mathrm{PaCO}_{2} 153.6\right.$ mmHg; $\mathrm{PaO}_{2} 17 \mathrm{mmHg} ; \mathrm{HCO}_{3}^{-} 13.6 \mathrm{mEq} / \mathrm{L}$; basis excess $-25.8 ; \mathrm{Na}^{+} 143.6 \mathrm{mEq} / \mathrm{L} ; \mathrm{K}^{+} 5.38$ $\mathrm{mE} / \mathrm{L}$; anion gap 34.1; Glu $702 \mathrm{mg} / \mathrm{dL}$ ). During resuscitation efforts, the patient received tenecteplase $50 \mathrm{mg}$ iv due to serious clinical suspicion of pulmonary embolism. Unfortunately, resuscitation was carried out for $60 \mathrm{~min}$ to no avail and the patient was pronounced dead. On post-mortem examination massive pulmonary embolism, with both macroscopic (in both pulmonary arteries) and microscopic foundlings (thrombi throughout the smaller arterial vessels in both lungs), confirmed the clinical diagnosis.

\section{Discussion and mini review of the literature}

Foot and ankle trauma or lower extremity surgery may lead to a higher incidence of venous thromboembolism due to stasis, vascular injury and immobilization. In addition, there are several other predisposing risk factors that may also increase VTE incidence. They are principally classified into non-modifiable (genetic: antithrombin, protein $\mathrm{C}$ and protein $\mathrm{S}$ deficiencies, Factor $\mathrm{V}$ Leiden mutation, the prothrombin 20210A variant, higher Ddimer, etc.), modifiable (obesity consuming $>1.5$ servings of red and processed meat daily, homocysteine levels) and temporary (hospitalization, oral contraceptive therapy, airline travel) factors. 1,2

It is difficult to determine which patients require prophylaxis because little is known about the risk of DVT in patients with lower extremity injuries. Various studies report various incidences. SooHoo et al. ${ }^{3}$ reported PE rate of $0.34 \%$ (DVT rate not reported), Mizel et al. ${ }^{4}$ reported PE rate of $0.15 \%$ and DVT rate of $0.22 \%$, Hanslow et al..$^{5}$ higher rate of both PE (1.3\%) and DVT (4\%) - yet their study included trauma patients -, Lipidus et al. ${ }^{6}$ and Jorgensen et $a l .{ }^{7}$ found even higher rates of DVT (17 and 28\% respectively), probably because they examined asymptomatic VTE and performed venography in all patients. Moreover, the second study did not clarify the
Correspondence: Theodoros Aslanidis, Mobile Intensive Care Units, National Center of Emergency Care, Thessaloniki Department, 54633 Thessaloniki, Greece.

Tel. +30.697.2477166

E-mail: thaslan@hotmail.com

Key words: pulmonary embolism, thromboembolic disease, ankle fracture.

Contributions: SC contributed to the management and recording of the case; SP and TA reviewed the literature; TA drafted the manuscript. All authors read and agreed to the final version of this manuscript.

Conflict of interests: the authors declare no potential conflict of interests.

Received for publication: 29 June 2014

Revision received: 17 August 2014

Accepted for publication: 18 August 2014

This work is licensed under a Creative Commons Attribution 3.0 License (by-nc 3.0).

(C) Copyright S. Charitidou et al., 2014

Licensee PAGEPress, Italy

Emergency Care Journal 2014; 10:4473

doi:10.4081/ecj.2014.4473

nature of the plaster cast (above- or belowknee) and included patients with different injuries. A fact that may also bias the incidence of DVT. In another trial, Patil et al. ${ }^{8}$ reported 5\% of non-clinical DVT and zero cases of PE after assessment of 100 cases of isolated fractures of the ankle treated in a below-knee cast. Finally, in a large study of 4271 patients, Kavanagh et al. ${ }^{9}$ reported the rate of symptomatic VTE in patients with isolated ankle fractures to be relatively low with a DVT rate of $0.29 \%$, a PE of $0.36 \%$ and a combined VTE rate of $0.54 \%$. Numerous case reports of fatal PE are also found in the literature..$^{10,11}$ The current recommendation from the American College of Chest Surgeons is that thromboprophylaxis is not recommended for isolated injuries below the knee. ${ }^{12}$ Considering the low incidence of symptomatic DVT and PE found in the literature and the relatively high cost of the routine prophylaxis strategy, these recommendations appear to be appropriate. Yet, cases like those aforementioned show that this policy may be debatable. We need large scale studies to really determine if the current guidelines need modifications and to what extent.

\section{Conclusions}

Routine pharmacological prophylaxis to patients requiring prolonged immobilization 
in a cast rather than the current practice of selective use of prophylaxis in high-risk patients is debatable. Cases of fatal pulmonary embolism in otherwise healthy low-risk patients prove that larger studies need to be carried out to come to a definite conclusion.

\section{References}

1. Baglin T, Luddington R, Brown K, Baglin C. Incidence of recurrent venous thromboembolism in relation to clinical and thrombophilic risk factors: prospective cohort study. Lancet 2003;362:523-6.

2. Cushman M. Epidemiology and risk factors for venous thrombosis. Semin Hematol 2007;44:62-9.

3. SooHoo NF, Krenek L, Eagan MJ, et al. complication rates following open reduction and internal fixation of ankle frac- tures. J Bone Joint Surg 2009;91:1042-9.

4. Mizel MS, Temple H, Michelson JD, et al. Thromboembolism after foot and ankle surgery: a multicenter study. Clin Orthop Relat R 1998;348:180-5.

5. Hanslow SS, Grujiec L, Slater HK, Chen D. Thromboembolic disease after foot and ankle surgery. Foot Ankle Int 2006;27:6935.

6. Lipidus LJ, Ponzer S, Elvin A, et al. Prolonged thromboprophylaxis with dalteparin during immobilization after ankle fracture surgery. Acta Orthop 2007;78:52835.

7. Jorgensen PS, Warming T, Hansen $\mathrm{K}$, et al. Low molecular weight heparin (innohep) as thromboprophylaxis in outpatients with a plaster cast: a venographic controlled study. J Thromb Res 2002;105:477-80.

8. Patil S, Gandhi J, Curzon I, Hui ACW. Incidence of deep-vein thrombosis in patients with fractures of the ankle treated in a plaster cast. J Bone Joint Surg Br 2007;89:1340-3.

9. Kavanagh M, Funahashi T, Maletis G, et al. Incidence of symptomatic venous thromboembolism after operative and non-operative ankle fractures. Available from: www.kpimplantregistries.org/Publications/ Posters/poster_anklefxs.pdf

10. Schrader MW, Ho AK, Notrica DM, Segal LS. Pulmonary embolism following ankle fracture in a 9-yr old boy: a case report. Acta Orthop Belg 2012;78:564-7.

11. Chen L, Soares D. Fatal pulmonary embolism following ankle fracture in a 17year-old-girl. J Bone Joint Surg 2006;88: 400-1.

12. Geerts WH, Bergvist D, Pineo GE, et al. Prevention of venous thromboembolism: the Eighth ACCP Conference on Antithrombotic and Thrombolytic Therapy. Chest 2008;133:381-453. 